\title{
Blood and Gastrointestinal Parasites of Chickens and Turkeys Reared in the Tropical Rainforest Zone of Southeastern Nigeria
}

\author{
M. N. Opara ${ }^{1 *}$, D. K. Osowa², J. A. Maxwell ${ }^{3}$ \\ ${ }^{1}$ Department of Veterinary Parasitology and Entomology, Faculty of Veterinary Medicine, University of Abuja, \\ Abuja, Nigeria \\ ${ }^{2}$ Department of Animal Science, Federal University of Technology, Owerri, Nigeria \\ ${ }^{3}$ Department of Health Services, Federal University of Technology, Owerri, Nigeria \\ Email: *oparamax@yahoo.com
}

Received 14 October 2014; revised 27 November 2014; accepted 10 Decemebr 2014

Copyright (C) 2014 by authors and Scientific Research Publishing Inc.

This work is licensed under the Creative Commons Attribution International License (CC BY).

http://creativecommons.org/licenses/by/4.0/

c) (i) Open Access

\begin{abstract}
The blood and gastrointestinal (GI) parasites of chickens and turkeys reared in Owerri, Southeastern Nigeria were studied. Out of 5600 birds, $5040(90 \%)$ were chickens and $560(10 \%)$ were turkeys. Of these birds, $672(12 \%)$ were infected with blood parasites, of which $448(8.9 \%)$ were chickens and $224(40 \%)$ turkeys. The blood parasites found in chickens were Leucocytozoon sp., with a prevalence rate of $448(8.9 \%)$ occurring in both male and female chickens examined. Plasmodium sp. was found in the turkeys and it gave a prevalence of $224(40 \%) .1792(32 \%)$ of the birds were infected with faecal parasites, out of which, $1456(28.9 \%)$ were chickens and 336 (60\%) turkeys examined. Ascaridia sp. infected 1232 (24.4\%) of the chickens and $336(60 \%)$ of the turkeys were examined. The only cestode observed was Raillietina spp., which infected $224(4.4 \%)$ of the chickens, but none in the turkeys. Generally, low blood and faecal infections were observed in the chickens, while infections in the turkeys were slightly higher.
\end{abstract}

\section{Keywords}

Blood, Gastrointestinal, Chickens, Turkeys, Tropical Rainforest, Nigeria

\section{Introduction}

The poultry industry occupies an important position in the provision of animal protein (meat and egg) to man ${ }^{*}$ Corresponding author.

How to cite this paper: Opara, M.N., Osowa, D.K. and Maxwell, J.A. (2014) Blood and Gastrointestinal Parasites of Chickens and Turkeys Reared in the Tropical Rainforest Zone of Southeastern Nigeria. Open Journal of Veterinary Medicine, 4, 308-313. http://dx.doi.org/10.4236/ojvm.2014.412037 
and generally plays a vital role in the national economy as a revenue provider. Chicken is one of the most intensively reared of the domesticated poultry species and the most developed and profitable animal production enterprise. Poultry production in Africa and parts of Asia is still distinctively divided into commercialized and village enterprise subsector, each with its peculiarities [1].

Poultry production specifically includes chickens, ducks, guinea fowl, turkey and ostrich. Turkey and chicken productions however make up the main component of the commercial poultry.

The Gallus domesticus can easily be infested with several types of bacterial, viral, fungal and parasitic pathogen [2]. The two types of internal parasites that affect poultry are worm's protozoa. Parasitism ranks high among factors that threaten chicken production [1]. Mortality due to parasitic disease is higher than that of Newcastle disease, an acknowledged most endemic and mortality causing viral infestation.

Many field studies show that poultry maintained under free-range conditions may be heavily parasitized, therefore control measures such as preventing infections or chemotherapy are likely to improve weight gain and egg production. Among the various parasitic diseases, haemoparasites infections are the most prevalent [2].

The haemoparasites mainly found in poultry in the tropical areas include the following genera: Plasmodium sp., Leucytozoon sp., Haemoproteus sp., Aegytinella sp., Trypanosoma sp. and microfilariasis of nematodes belonging to the suborder filariata [3].

Modern confinement rearing of poultry has significantly reduced the frequency and variety of these endoparasite infections which are common in free-range birds and backyard flocks [4]. However, severe parasitism still may occur in floor-reared layers, breeders, turkeys, or pen-reared game birds. Multiple helminthiasis is common in poultry kept extensively, while heavy infections are common in intensively managed stock in which they cause severe pains that affect the normal activities of the birds resulting to death [5].

In addition, the role of poultry worms such as Heterakis gallinarum has been associated with the transmission of Histomonas meleagridis in turkeys and chicks [1]. It has been reported [6] that parasitic infections or their concurrent infections result in immunosuppression, especially in response to vaccine against some poultry diseases.

Poultry production has remained the main stay of the Nigeria livestock production industry and a major contributor to the economy and the gross national product (GNP). It is however unfortunate that currently, there is a paucity of information regarding the prevalence of endoparasites of chickens and turkeys in study area, despite its numerous importance. For a fast growing economy like Nigeria, however, there is a need to continually revalidate existing data on the health of chickens and turkeys at regular intervals. In addition, as co-factors in other poultry diseases, the knowledge of their prevalence is essential in understanding the epidemiology control measures [1].

Thus a comprehensive report of blood and gastro intestinal parasites of chickens and turkeys should be based on field surveys and experimental researches.

In spite of the fact that poultry production is fast growing and becoming a major enterprise in Nigeria in general and Owerri in particular, accurate information on the prevalence of these parasites is still opaque and not generally known or reported. Therefore, adequate information on the prevalence of these parasites, their control and management practices adopted are vital, since such information could be useful to commercial and local poultry farmers in Owerri and Nigeria at large.

\section{Materials and Methods}

\subsection{Study Site}

Owerri is the capital city of Imo State, within the south east and covers an area of $5288 \mathrm{sqkm}$. It lies between latitude $40^{\circ} 45^{\prime} \mathrm{N}$ and $70^{\circ} 15^{\prime} \mathrm{N}$ and longitude $60^{\circ} 50^{\prime} \mathrm{E}$ and $70^{\circ} 25^{\prime} \mathrm{E}$ (www.imostate.gov.ng).

The rainy season here begins in March and ends in October with a break in August. The total rainfall decreases from $2200 \mathrm{~mm}$ in the southern to $1900 \mathrm{~mm}$ in the northern parts of the State. The hottest months range from January to March, when the mean temperature is above $27^{\circ} \mathrm{C}$. The relative humidity is usually high throughout the year, reaching a maximum during the rainy season when values above $90 \%$ are recorded (www.abiastate.gov.ng).

\subsection{Samples Collection and Analysis}

Male and female sexes of 5040 chickens and 560 turkeys were purposively randomly selected from different 
poultry farms in Owerri, the tropical rainforest zone of southeastern Nigeria. Blood and faecal samples were taken from each of the birds randomly selected from the wing vein and per rectum respectively and examined for parasites, using standard parasitological techniques [2] [7] [8]. Thin smear was prepared from the blood, stained with Giemsa and observed microscopically at $\times 100$, using oil immersion. The fecal samples were subjected to both the simple floatation and sedimentation methods to observe the helminth ova and oocyts in them. The slides were thereafter examined under the microscope at $\times 10$ magnification. Data obtained for blood and gastrointestinal parasites were analyzed using simple descriptive statistics.

\section{Results}

Out of 5600 birds examined, 5040 (90\%) were chickens and 560 (10\%), turkeys (Table 1). Of the birds examined, 672 (12\%) were infected with blood parasites and 1792 (32\%) infected with gastrointestinal parasites. Haemoparasites infection in chickens was 448 (8.9\%) and 224 (40\%) in the turkeys. Gastrointestinal parasites yielded 1456 (28.9\%) prevalence rate in chickens, while 336 (60\%) of the turkeys examined were infected.

The results of parasitic infections of the chickens according to their sexes are presented in Table 2. Out of 1232 (24.4\%) cockerels examined, 224 (18.2\%) of them were infected with haemoparasites and the same number of them (224, 18.2\%) were infected with GI parasites. Of the 3808 (75.6\%) hens examined, 224 (5.9\%) and 1232 (32.4\%) of them were infected with blood and GI parasites respectively.

Our results in Table 3 showed that, of the 336 (60\%) male turkeys examined, 112 (33.3\%) were infected with blood parasites, while the same number of them, (112, 33.3\%) harboured GI parasites. Female turkeys examined were 224 (40\%). The population of these that were infected was $112(50 \%)$ and 224 (100\%) for blood and GI parasites respectively.

Table 4 shows the species prevalence of blood parasites of chickens reared in Owerri, the tropical rainforest zone of southeastern Nigeria. Out of 5040 chickens examined, 448 (8.9\%) were infected with Leucocytozoon sp. This was the only blood parasites encountered among the chickens in this study. Plasmodium sp. was observed in the blood of the turkeys examined and 224 (40\% of them were infection with this haemoparasite.

The prevalence of the species of GI parasites among chickens and turkeys reared in Owerri is presented in Table 5. Of the chickens examined in the study, 1232 (24.4\% were infected with Ascaridia sp., while 224 (4.4\%) were infected with Raillietina sp. Out of the 560 turkeys examined, 336 (60\%) of them were infected with Ascaridia sp. and no cestode infection was observed.

Table 1. Blood and GI parasites of chickens and turkeys reared in Owerri Southeastern Nigeria.

\begin{tabular}{cccc}
\hline Bird species & No. (\%) exam & No. (\%) infected with blood parasites & No. (\%) infected with GI parasites \\
\hline Chickens & $5040(90)$ & $448(8.9)$ & $1456(28.9)$ \\
Turkeys & $560(10)$ & $224(40)$ & $336(60)$ \\
Total & 5600 & $672(12)$ & $1792(32)$ \\
\hline
\end{tabular}

Table 2. Blood and GI parasites according to sex of chickens reared in Owerri Southeastern Nigeria.

\begin{tabular}{cccc}
\hline Sex of chickens & No. (\%) exam & No. (\%) infected with blood parasites & No. (\%) infected with GI parasites \\
\hline Male & $1232(24.4)$ & $224(18.2)$ & $224(18.2)$ \\
Female & $3808(75.6)$ & $224(5.9)$ & $1232(32.4)$ \\
Total & $5040(90)$ & $448(8.9)$ & $1456(28.9)$ \\
\hline
\end{tabular}

Table 3. Blood and GI parasites according to sex of turkeys reared in Owerri Southeastern Nigeria.

\begin{tabular}{cccc}
\hline Sex of turkeys & No. (\%) exam & No. (\%) infected with blood parasites & No. (\%) infected with GI parasites \\
\hline Male & $336(60)$ & $112(33.3)$ & $112(33.3)$ \\
Female & $224(40)$ & $112(50)$ & $224(100)$ \\
Total & $560(10)$ & $224(40)$ & $336(60)$ \\
\hline
\end{tabular}


Table 4. Prevalence of species of blood parasites of chickens and turkeys reared in Owerri Southeastern Nigeria.

\begin{tabular}{cccc}
\hline Bird species & No. (\%) exam & No. (\%) infected with Leucocytozoon sp & No. (\%) infected with Plasmodium sp \\
\hline Chicken & $5040(90)$ & $448(8.9)$ & - \\
Turkey & $560(10)$ & - & $224(40)$ \\
Total & 5600 & $448(8)$ & $224(4)$ \\
\hline
\end{tabular}

Table 5. Prevalence of species of GI parasites of chickens and turkeys reared in Owerri Southeastern Nigeria.

\begin{tabular}{cccc}
\hline Bird species & No. (\%) exam & No. (\%) infected with Leucocytozoon sp & No. (\%) infected with Plasmodium sp \\
\hline Chicken & $5040(90)$ & $1232(24.4)$ & $224(4.4)$ \\
Turkey & $560(10)$ & $336(60)$ & - \\
Total & 5600 & $1568(28)$ & $224(4)$ \\
\hline
\end{tabular}

\section{Discussion}

The prevalence of blood parasites of chickens and turkeys in this study was $12 \%$ with $8.9 \%$ for chickens and $40 \%$ for turkeys. This result partially agrees with [9], who reported a prevalence of $14 \%$ among local chickens reared in Imo State. Elsewhere, [10] also reported a prevalence of 14\% among chickens in Zimbabwe. However, our result is not consistent with the results in Ghana [11], which was $27 \%$ and $71 \%$ for Malawi [12]. More so, a prevalence of $61.9 \%$ has been reported in Uganda [13]. This huge difference might be attributed to difference in environmental conditions for the birds and parasites and management practices adopted by the farmers in these areas. None of these workers investigated the prevalence of blood parasites in turkeys reared in their different locations.

The overall prevalence of faecal parasites for chickens and turkeys reared in Owerri was 32\% (chickens, 28.9\% and turkeys, 60\%). This does not agree with [14], who reported a prevalence of $87.0 \%$ in free ranging chickens in Bauchi, Savannah zone of Nigeria. The high prevalence rate of $60 \%$ in the turkeys suggest that there are favourable environmental conditions around the farm where are reared, which are necessary for helminth eggs survival and high reproductive efficiency of these parasites.

This wide difference in the prevalence of helminthes in these studies could be due to the differences in the feeding patterns of the birds, incidence of the infective stages and intermediate hosts of the parasites picked up by the birds or found in places where the chickens free-ranged. The prevalence and intensity of helminthes infections may be influenced by several factors such as distribution of intermediate hosts and/or their infection rate and the number of infective parasite eggs or larvae. It has also been reported that absence of biosecurity and scavenging habits of chickens in free range conditions can also contribute to high helminth infections [2] [15]. The prevalence of helminthes in turkeys was $60 \%$ and this agrees with [16], who found a prevalence of $61.9 \%$ in free-ranging turkeys in Samaru, Zaria.

Blood infection was higher in the male than female chickens. The reason(s) for this huge difference cannot be explained here. This might be an area for a future research. The prevalence of GI parasites was more in the female than male chickens. The reasons for the higher GI infection could be attributed to the fact that male chickens under any condition of management, tend to court the females by allowing them to feed first before the males and even more. In so doing, they are more likely to easily acquire infective pathogens than the females. In addition, stress due to egg laying and other reproductive activities could reduce the immunity of the females to infections [17].

The prevalence of both the blood and GI parasites were comparatively higher in the female than male turkeys, even though more males than females were examined in this study. The reason(s) for this sexual dimorphism might be due to the differences in their reproductive activities, as earlier reported [17].

The prevalence of helminthes in turkeys which was $60 \%$ agrees with [16], who found a prevalence of $61.9 \%$ in free-ranging turkeys in Samaru, Zaria.

A prominent feature of this study was the complete absence of trematodes. This is in conformity with the works [18] and [14] that similarly did not find any trematodes among birds examined in different parts of northern Nigerian. 
Chickens examined in this study were mainly infected with Leucytozoon sp., while the turkeys were infected with Plasmodium sp. This result is in agreement with an earlier report [3], that the haemoparasites mainly found infecting poultry in the tropical areas include Plasmodium spp., Leucocytozoon sp., Haemoproteus sp., Aegyptinella sp., Trypanosoma sp. However, Haemoproteus sp., Aegyptinella sp. and Trypanosoma sp. were not encountered in this study. Plasmodium parasites were not observed in the blood of the chickens examined. This result is in agreement [19], who also did not find Plasmodium parasites in domestic chickens in northeastern Nigeria.

Leucocytozoonosis causes a more severe disease in young birds, which manifests with inappetence, weakness, listlessness, dyspnoea and sometimes death within 24 hours. The signs in the adult chickens appear less dramatic and consist of listlessness and a low mortality rate [20]. Some other pathologic manifestations of the disease are anaemia, leukocytosis, splenomegaly, liver degeneration and hypertrophy [20]. Thus, its prevalence rate of $8.9 \%$ found among chickens in the present study could be comparatively low, hence the lack of mortality. Although there are a very limited number of studies on blood parasites of avian species [21] [22], there is no report describing the occurrence of Leucocytozoon sp. in turkeys.

Information on avian malaria in turkeys is scarce. However, in this study, its prevalence rate was $40 \%$ among the turkeys examined. This is higher than the prevalence rates, 27\%, 29.5\% and 15\% earlier reported [11] [12] [23] for chickens in Ghana, Malawi and Zimbabwe respectively.

Plasmodium sp. causes avian malaria in poultry. Generally avian malaria is not of major veterinary importance in commercial production systems, but may cause losses. However, among free ranging chickens high mortality rates can be seen due to Plasmodium spp. infections and more importantly, immunosuppression might take place.

The birds examined were mostly infected with the nematode Ascaridia sp., while Raillietina sp., the only cestode found was among the chickens. This finding agrees with [24], that the population of nematodes, far outweighs those of trematodes and cestodes and they establish themselves in their hosts faster than the others. Most species of nematodes and cestodes are also involved in Parasitic-gastroenteritis in animals.

The incidence, severity and disease prevalence of helminthes have been shown to vary with management systems. It has been reported that, while infections accounted for over half of the disease conditions observed in a group of intensively managed animals, they were of negligible prevalence in a controlled group raised semi-intensively. The birds reared in Owerri are semi-intensively managed.

\section{Conclusions}

This study showed that blood and gastrointestinal parasites constantly infected chickens and turkeys reared in Owerri, Imo State. The study revealed that haemoparasites infection is less frequently seen in farm poultry birds. This shows that these birds are in good health condition, while the presence of high parasitic loads shows unhygienic environmental conditions, where the birds are reared.

Some of the blood parasites observed in the birds are of economic importance. For example, Plasmodium causes avian malaria and Leucocytozoonosis is pathogenic in younger birds.

Consistency in the use of dewormer, regular treatment of helminth infected birds and control of the intermediate hosts should be carried out to break transmission of the parasites.

Further research is suggested to assess the impact of these parasites on the health and production performance of the chickens including cost effectiveness of control strategies.

\section{References}

[1] Nnadi, P.A. and George, S.O. (2010) A Cross-Sectional Survey on Parasites of Chickens in Selected Villages in the Subhumid Zones of South-Eastern Nigeria. Journal of Parasitological Research, 2010, Article ID: 141824.

[2] Soulsby, E.J.L. (1982) Helminths, Arthropods and Protozoa of Domesticated Animal. 7th Edition, Bailliare Tindall, East Sussex.

[3] Permin, A. and Hanson, J.W. (1998) Epidemiology, Diagnosis and Control of Poultry Parasites. FAO Animal Health Manuals 4 Rome, Food and Agriculture Organization of the United Nation.

[4] Rod, C., Tom, I. and Jeromie, M. (2008) The Responsible Use of Health Management Products for Poultry Production. National Library of Canada Cataloguing.

[5] FAO (2004) Small Scale Poultry Production in Nigeria. http://www.fao.org/../y5169e07 
[6] Ekpo, U.F., Ogbooye, A.A., Olumoye, A.S. and Takeet, M. (2010) A Preliminary Survey on the Parasites of Free Range Chickens in Abeokuta, Ogun State Nigeria. Journal of National Engineering Technology, 2, 123-130.

[7] MAFF (Ministry of Agriculture, Fisheries and Food) (1986) Manual of Veterinary Parasitological Laboratory Techniques, ADAS, HMSO, UK.

[8] Urguhart, G.M., Armour, J., Duncan, I.J., Dunn, A.M. and Jennings, F.W. (1996) Veterinary Parasitology. In: Urguhart, G.M., Armour, J., Duncan, I.J., Dunna, A.M. and Jennings, F.W., Eds., 2nd Edition, Blackwell Science, London, 67-137.

[9] Okereke, R.E. (2010) Occurrence of Blood Parasites in Local and Exotic Chickens Slaughtered in Owerri, Imo State. B-Agri-Technology Project Report Submitted to the Department of Animal Science and Technology, Federal University of Technology, Owerri.

[10] Permin, A., Esmann, J.B., Hoj, C.H., Hove, J. and Mukara, T.S. (2002) Ecto-Endo and Haemoparasite in Free-Range Chickens in Goromonzi District in Zimbabwe. Preventive Veterinary Medicine, 54, 213-224. http://dx.doi.org/10.1016/S0167-5877(02)00024-7

[11] Poulsen, J., Permin, A., Hindsho, O., Yelifari, L., Nansen, P. and Bloch, P. (2000) Prevalence and Distribution of Gastrointestinal Helminthes and Haemoparasites in Young Scavenging Chickens in Upper Eastern Region of Ghana West Africa. Preventive Veterinary Medicine, 45, 237-245. http://dx.doi.org/10.1016/S0167-5877(00)00125-2

[12] Njuga, G.R. (2000) Ecto- and Haemoparasites of Chickens in Malawi with Emphasis on the Effects of the Chicken Louse, Menacanthus cornutus. M.Sc. Thesis, University of Malawi, Lilongwe.

[13] Valkiūnas, G., Sehgal, R.N., Iezhova, T.A. and Smith, T.B. (2005) Further Observations on the Blood Parasites of Birds in Uganda. Journal of Wildlife Diseases, 41, 580-587. http://dx.doi.org/10.7589/0090-3558-41.3.580

[14] Yoriyo, K.P., Fabiyi, J.P., Adams, S.U. and Panda, S.M. (2005) Intensities of Helminth Parasites of Free Ranging Chickens in Bauchi and Environs. Yankari Journal, 2, 135-137.

[15] Permin, A., Magwisha, H., Kassuku, A.A., Nansen, P., Bisgaard, M., Frandsen, F. and Gibbsons, L. (1997) A CrossSectional Study of Helminthes in Rural Scavenging Poultry in Tanzania in Relation to Season and Climate. Journal of Helminthology, 71, 233-240. http://dx.doi.org/10.1017/S0022149X00015972

[16] Luka, S.A. and Ndam, I.S. (2007) Grastrointestinal Parasites of Domestic Chickens, Gallus domestic (Linnaeaus 1758) in Samaru, Zaria, Nigeria. Science World Journal, 2, 27-29.

[17] Opara, M.N. and Nwokedi, C.C. (2011) Occurrence of Haemoparasites among Small Ruminants Reared under Traditional Husbandry System in Owerri, Southeast Nigeria. Bulletin of Animal Health and Production in Africa, 59, 393398.

[18] Fabiyi, J.P. (1972) Incidence of Helminth Parasites of Domestic Fowls in Vom Area of Benue-Plateau State, Nigeria. Bulletin of Epizootic Disease of Africa, 20, 229-243.

[19] Igbokwe, I.O., Hassan, S.U., Faive, Z.T., Iliya, Y., Dagare, M.J., Rabo, J.S., Mohammed, A. and Igbokwe, N.A. (2008) Effect of Plasmodium Species Infections on Packed Cell Volume of Domestic Chickens and Helmeted Guinea Fowls, North Eastern Nigeria. Animal Research International, 5, 892-895.

[20] Schmidt, G.D. (1986) Handbook of Tapeworm Identification. CRC Press, Boca Raton, 24.

[21] Tadelle, D. (1996) Studies on Village Poultry Production System in the Central Highlands of Ethiopia. M.Sc. Thesis, Swedish University of Agricultural Sciences, Uppsala.

[22] Gicik, Y. and Arshan, M.O. (1999) Blood Parasites of Wild Pigeons in Ankara District. Turkish Journal of Veterinary and Animal Sciences, 25, 169-172.

[23] Maizels, R.M., Bundy, D.A.P., Selkirk, M.E., Smith, D.F. and Anderson, R.M. (1993) Immunological Modulation and Evasion by Helminth Parasites in Human Population. M.Sc. Seminar, Cellular Parasitology, University of Ibadan, Ibadan.

[24] Smith, D.B. and van Hautert, M.J.F. (1984) Health Aspects of Intensive Management of West African Dwarf Goats in the Humid forest Zone. Proceeding of the National Conference on Diseases of Ruminants, Vom, 3-6 October 1984, 813. 
Scientific Research Publishing (SCIRP) is one of the largest Open Access journal publishers. It is currently publishing more than 200 open access, online, peer-reviewed journals covering a wide range of academic disciplines. SCIRP serves the worldwide academic communities and contributes to the progress and application of science with its publication.

Other selected journals from SCIRP are listed as below. Submit your manuscript to us via either submit@scirp.org or Online Submission Portal.
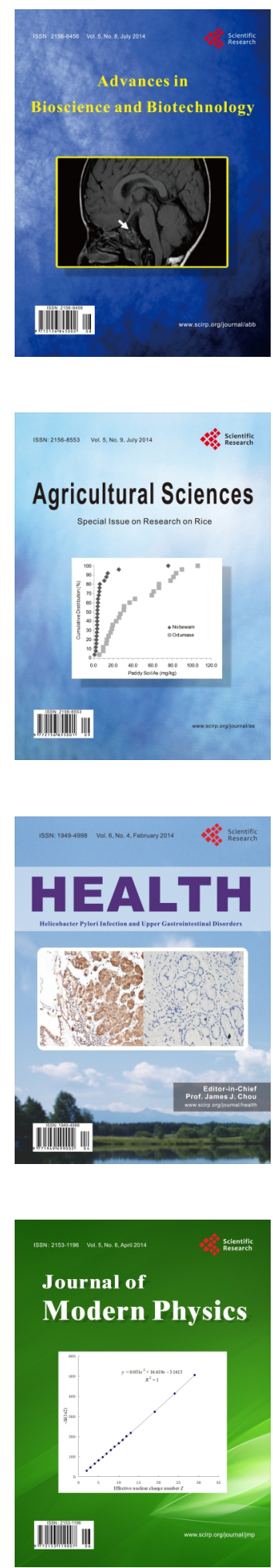
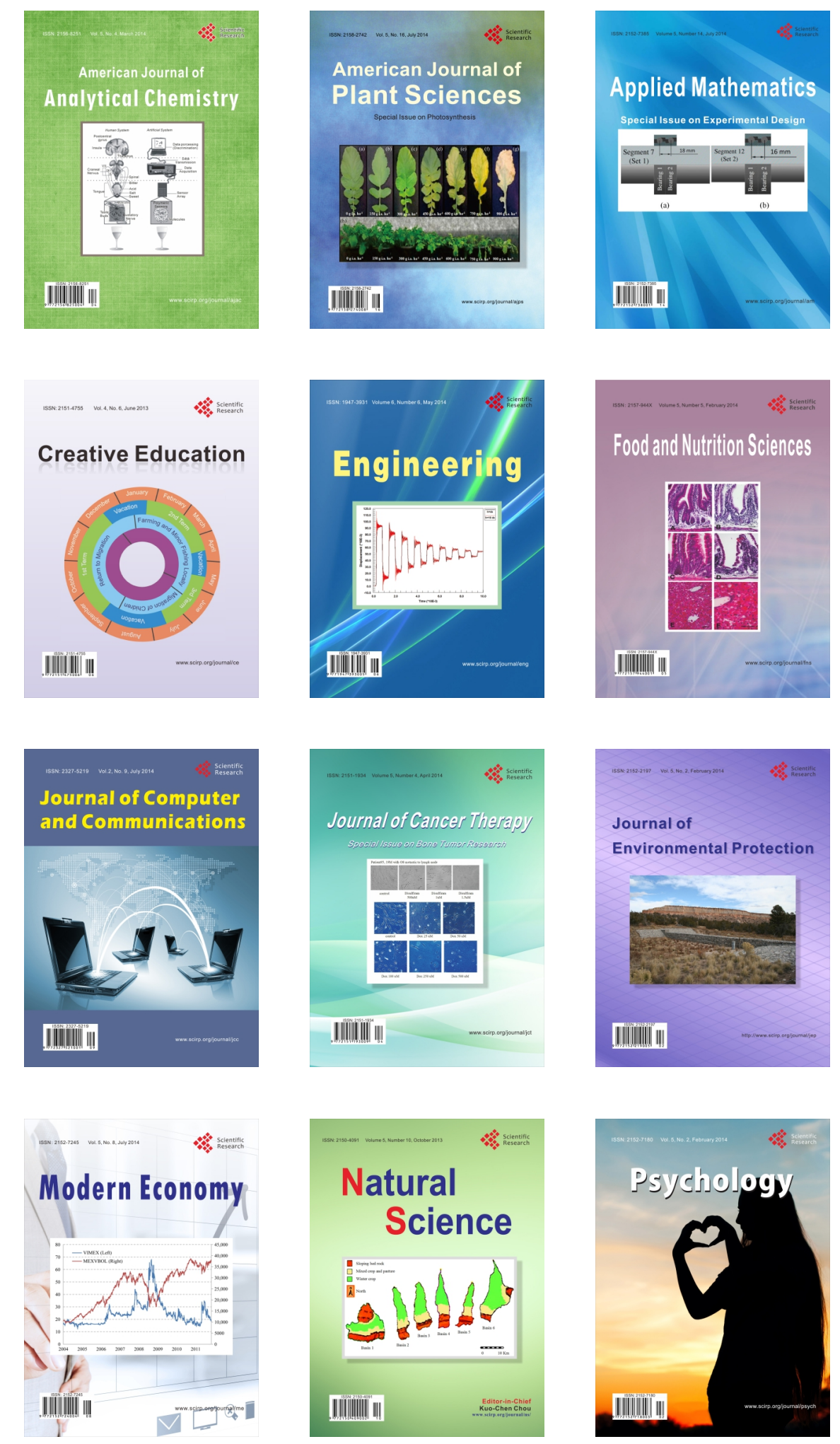